\title{
March 25 and All That
}

BY

\author{
ALEXANDER NADSON*
}

\author{
Short Bibliographical Guide to Works \\ on the Struggle for Belarusian Independence 1900-21 \\ in the Francis Skaryna Belarusian Library in London
}

\begin{abstract}
'We, the Council (Rada) of the Belarusian Democratic Republic, have cast off from our native land the last vestige of national dependence which the Russian tsars imposed by force upon our free and independent land. From this time on, the Belarusian Democratic Republic is proclaimed an independent and free state.'
\end{abstract}

These words are taken from the Declaration of Independence made by the Council of the Belarusian Democratic Republic in Minsk on 25 March 1918. Owing to the unfavourable political situation the independence of the state did not last long. All the same, from that day on Belarusians all over the world keep the 25 March as their Independence Day.

In 1772-95 Belarus was occupied by Russians and became part of the Russian Empire. The tsarist authorities regarded it simply as the North West Region (Severozapadnyi krai) of Russia, inhabited by people speaking a kind of peasant Russian dialect. Consequently all signs of individuality were systematically eradicated, including the destruction in 1839 of the Greek-Catholic (Uniate) Church to which the majority of Belarusians belonged. The opposite view was held by Poles, or rather by polonised Belarusian landed gentry, for whom Belarus was a Polish province. Despite this, the Belarusian national movement began to manifest itself early in the 19th century, and gathered momentum especially after the emancipation of peasants in 1861. In 1862 the revolutionary leader Kastuś Kalinoŭski (hanged by the Russians in 1864) began publishing the clandestine paper Mužyckaja Praŭda (Peasant Truth). Some twenty years later the Belarusian group of the movement Narodnaja Volia (People's Freedom) in their underground paper Homon was already raising the question of Belarusian autonomy.

Fr Alexander Nadson is the Apostolic Visitor for Belarusian Greek-Catholic faithful abroad and the director of the Francis Skaryna Belarusian Library and Museum in London. 
The end of the 19th century also saw the appearance of new Belarusian writers and poets, the most prominent of whom was Francišak Bahuševič (1840-1900) who reminded the Belarusians: 'Do not abandon our Belarusian language that we may not die'. But it was not until 1903 that the first Belarusian party, the Bielaruskaja Revaliucyjnaja Hramada (Belarusian Revolutionary Party) was founded. Two years later, under its definitive name of Bielaruskaja Sacyjalistyčnaja Hramada (Belarusian Socialist Party) it played an active role in the revolution of 1905-07. In the years that followed members of the Hramada were closely connected with the newspaper Naša Niva (Our Field) which, until its closure in 1915 was the focal point of Belarusian political and cultural life. The Hramada was the only Belarusian political party during that period. Other parties then active in the area - Russian, Polish, Jewish, - were, with few exceptions, indifferent or even openly hostile to Belarusian national aspirations.

One year after the outbreak of the First World War, in summer 1915, Belarus was divided by the frontline between the German and Russian armies. The hardships caused by the war were aggravated by the refugee problem: before abandoning Western Belarus to the Germans, the Russian authorities evacuated over a million of its inhabitants who were taken inside Russia and largely left to their own fate. This was the situation in Belarus at the time of the February Revolution of 1917. From then on events began to move rapidly.

The Provisional Russian government of Kerenskii was replaced in its turn, and in February 1918, abandoned the area to the Germans. In December of the same year the Germans retreated, and Communist Soviet rule was established again in Belarus with the exception of the Horadnia (Hrodna) region in the West. During the late spring and early summer of 1919 Belarus was invaded by the Poles who remained there until summer 1920. Against this background of an ever-changing political scene the Belarusians tried to establish their own independent state. Their efforts led to the convocation in December 1917 in Minsk of an All-Belarusian Congress and, finally the proclamation on 25 March 1918 of the independent Belarusian Democratic Republic (Bielaruskaja Narodnaja Respublika, abbreviated as BNR). The odds were, however, against them.

In December the Council and Government of the BNR left Minsk and established themselves in Horadnia which at that time was the centre of a semiautonomous Belarusian region within the Lithuanian Republic. The Polish invasion in spring of 1919 put an end to this, and the government of the BNR went into exile. The hopes of some of its members that the Poles would help in re-establishing Belarusian independence were soon dispelled. In the meantime the Soviet authorities who, like the Russian Provisional Government before them, were hostile to the idea of Belarusian independence began to take notice of the strong national 
feelings among Belarusians and of the pressure exerted by various Belarusian refugee organisations inside Russia. On 1 January 1919 the Belarusian Soviet Socialist Republic (abbreviated as BSSR, initially called the Soviet Socialist Republic of Belarus or SSRB) was proclaimed. The new 'state' did not exist for long as a separate entity: in February of the same year it became part of a new creation called the Lithuanian-Belarusian Soviet Socialist Republic. As the hopes of establishing Soviet rule in Lithuania receded, the idea of the latter was abandoned, and in summer 1920 the BSSR was restored in its original form. Territorially, however, the Republic comprised only a tiny part of Eastern Belarus ( domination. This partition of Belarus was finally ratified in 1921 by the SovietPolish Treaty of Riga, and lasted until 1939.

The foregoing short account gives an idea of the complexity of the problem faced by the student of Belarusian history during the first two decades of the 20th century. The task is not made easier by the absence of a reliable bibliographical guide. What follows is not intended to be such a guide, but merely a description of some of the relevant material available in the Francis Skaryna Belarusian Library in London.

Among the few bibliographical works there is A Bibliographical Guide to Belorussia by N. Vakar (Harvard U.P. 1956). Its section on the period in question (Nos 1022-1160 and 1384-1509) is useful at least as a beginning. Another work, Bibliahrafija pa historyi Bielarusi by M. Krakene and A. Sakolčyk (Minsk 1969), contains a large section (Nos 3782-4453) on the period from 1900 to the February 1917. Only works in Belarusian, Russian and Ukrainian are listed, and by no means all of them. Works of authors such as U. Ihnatoŭski, A. Stankievič, A. Luckievič, A. Ćvikievič, J. Najdziuk and others have been omitted.

To understand the events of 1900-21 a knowledge of the preceding period at least from 1861 is useful. An account of the whole period 1861-1921 in vols 2 and 3 of the five-volume 'academic' Historyja Bielaruskaj SSR (Minsk 1971-75) represents the official Soviet point of view, and suffers from the usual defects of works of this kind, namely partiality and omission of inconvenient facts. The new 'academic' work, Narysy pa historyi Bielarusi, ed. M. Kasciuk et al. (2 vols, Minsk 1994-95), is an attempt at a more balanced view of history. The other general works on Belarus history, including chapters on the period in question, are Bielaruś učora i siannia by J. Najdziuk (Minsk 1943; 2nd ed. Minsk 1993); Weissruthenien: Volk und Land by E. von Engelhardt (Berlin 1943); and Belorussia: the Making of a Nation by N. Vakar (Harvard U.P. 1957), the latter being written in a somewhat patronising tone. J. Zaprudnik's Belarus at the Crossroads of History (BoulderOxford 1993; Belarusian edition Minsk 1996) is a serious work by a well-known Belarusian historian and can serve as an excellent introduction to the history of 
Belarus in general, and the Belarusian independence movement in particular. Another recent serious work which contains a large section on the period in question is Historia Białorusi (1795-2000) by Zachar Szybieka, in Polish (Lublin 2002); and his more extensive Belarusian version, Narys historyi Bielarusi 1975-2002 (Minsk 2003). Historyja Bielarusi XIX i pačatku XX stalećcia by U. Ihnatoŭski (Minsk 1926) deals with the period of Belarusian history from the beginning of the 19th century to 1921. A. Stankievič's Da historyi bielaruskaha palityčnaha vyzvaleńnia (Vilna 1934) is an interesting study of the Belarusian national movement between the years 1862-1921. Another work, covering roughly the same period, but concentrating particularly on the years 1905-20, is Belorusskoe dvizhenie by F. Turak (Moscow 1921; reprint Minsk 1992). It is a comprehensive and factual study of the period in question, written with rare objectivity and supported by a mass of documentary evidence. Ocherki po istorii revoliutsionnogo dvizheniia v Belorussii (1863 -1917) by S. Agurskii (Minsk 1928) is also well documented. Unlike Turuk, however, its author is mainly concerned with non-Belarusian parties, especially the RSDRP (as the Russian Communist party was then called).

Byelorussian Statehood, ed. V. \& Z. Kipel (New York 1988) is a source book on the Belarusian history of 1917-21, containing writings of persons who were directly involved in the events of 1917-21, such as Krečeŭski, Varonka, Zacharka, articles by historians J. Zaprudnik, P. Urban and J. Menski, biographical notes on over 60 Belarusian political leaders of the period, a bibliography and chronological table of events. It is a must for everyone interested in the history of the Belarusian struggle for national independence.

There is a scarcity of published documents on the period in question. The bulky volumes 3 and 4 of Dokumenty $i$ Materialy po istorii Belorussii (Minsk 1953 \& 1954), contain documents of 1900-17 and 1917-19 resp., all in Russian, and one would in vain look in them for any mention of Belarus, let alone the BNR. As far as Belarusian documents are concerned, apart from the above-mentioned book by Turuk (39 documents), one should mention Kryvavy šliach bielaruskaj nacdemokratyi by A. Ziuzkoŭ (Minsk 1932). The author, hostile to the Belarusian national movement, in an appendix gives the texts of 31 documents from 1917-21. Another major collection (58 documents) is found in Za dziaržaŭnuju niezaležnaść Bielarusi, ed. I. Kasiak (London 1960). A truly monumental work is Archivy Bielaruskaj Narodnaj Respubliki, ed. S. Šupa (2 books, Vilna-New York 1998), containing over 3000 documents of the BNR from the Lithuanian State Archives.

Among the works on the period 1900-17 there is first of all Za dvacać piać hadoŭ by A. Luckievič (Vilna 1928; 2nd ed. Minsk 1991, with postscript by A. Sidarevič). The author, one of the pioneers of the Belarusian national movement, traces the history of the first Belarusian political party, the Bielaruskaja 
Sacyjalistyčnaja Hramada, and recalls the persons and events connected with it. The chapter 'Bielaruskaje Nacyjanalnaje Adradžeńnie (1902-1915)' in the book $Z$ historyi Bielarusi by J. Stankievič (Munich 1958) contains much interesting material on the Belarusian national movement, in which the author took an active part. An assessment of the role played by the Communists in the Belarusian movement is found in Bolshevizm v revoliutsionnom dvizhenii Belorussii by $\mathrm{N}$. Nedasek (Munich 1956). An important aspect of the Belarusian national activities before 1917 is covered in J. Zaprudnik's doctoral thesis Political Struggle for Byelorussia in the Tsarist State Dumas 1906-17 (typescript, New York 1966) and a number of his articles on the same subject, such as 'The Struggle for Byelorussia's Autonomy in the First State Duma' (The Journal of Byelorussian Studies, Vol. II, No. 3, London 1971), and 'Byelorussia's Representatives in the Second State Duma' (Ibid., Vol. III, No. 3, 1975). The development of the Belarusian press, and in particular the newspaper, is the subject of the book Puciaviny Rodnaha Slova by S. Aleksandrovič (Minsk 1971), and the article 'Naša Niva' by the present writer (The Journal of Byelorussian Studies, Vol. I, No. 3, 1967). Incidentally, sets of the papers Naša Dolia (1906), and Naša Niva (for the years 1906-1911) are now available in facsimile editions. Bielaruski Litaraturna-Hramadski Ruch u Pieciarburzie by R. Siemaškievič (Minsk 1971) is a study of the Belarusian colony (mainly students) in St Petersburg and their role in the Belarusian national movement.

There are several eyewitness accounts of the events from February 1917 to 1921. E. Kancher in his Belorusskii Vopros (Petrograd 1919) left one of the first written accounts of the All-Belarusian Congress of December 1917 and the events leading to the proclamation of independence on 25 March 1918, of which he was not in favour. J. Varonka, the first prime minister of the BNR, gave his version of events in Belorusskii vopros $k$ momentu Versal'skoi Mirnoi Konferentsii (Kaunas 1919) and Bielaruski ruch ad 1917 da $1920 \mathrm{Hadu}$ (Kaunas 1920). Other contemporary publications are Korotkii ocherk vozniknoveniia Belorusskoi Narodnoi Respubliki by A. Ćvikievič (Kiev 1918), and Uschodniaja Bielaruś by A.I. (Minsk 1918), the latter giving a detailed picture of the growth of Belarusian movement leading to the declaration of independence. There is also the first and only issue of the journal Varta (Minsk 1918), a semi-official organ of the Belarusian Government. P. Krečeŭski, a member of the first Belarusian government and later President of the Council (Rada) of the BNR writes about the events of 1917-18 in his article 'Bielaruś u Minulym i Sučasnym' in the first (and only) issue of the journal Zamiežnaja Bielaruś (Prague 1926). Krečeŭski was succeeded by Vasil Zacharka who also took an active part in the First Belarusian Congress and the proclamation of the independence of the BNR on 25 March 1918, as well as the events that followed it. His Haloŭnyja momanty bielaruskaha ruchu (The Main Moments of the Belarusian Movement), written in 1926 (typescript in the Francis Skaryna 
Library in London), was finally published by the Belarusian Institute of Arts and Sciences in their Zapisy, No. 24, New York 1999, pp. 5-87.

'Da pieršaha usiebelaruskaha Zjezdu 1917', ed. I. Zaprudnik (Zapisy, Munich, No. 2, 1963; No. 3, 1964; No. 4, 1966) is a useful collection of materials and documents on the All-Belarusian Congress, compiled from publications not easily accessible today.

Attempts to form a Belarusian army are described in various articles, such as 'Bielaruskija vajskovyja farmacyi na rumynskim froncie' by S. K. (the journal Kryvich, No. 1, Kaunas 1923), 'Bielaruskaja vajskovaja Centralnaja Rada' by K. Jezavitaŭ (Ibid., No. 7, 1924, No. 9, 1925); 'Histaryčny kalendar bielaruskich addzielaŭ litoŭskaha vojska' by A. Sam. (Krynica, Vilna, No. 4, 1939; Nos 7, 16, 27, 40, 1940); 'Pieršy bielaruski polk u Horadni i jak paliaki razbroili jaho' by A. Uspieński (Ranitsa, Berlin, No. 44, 1943, et seq); '25 Uhodki horadzienskaje hubernskaje upravy' by V. B. (Ibid., No. 49-50, 1943; 1-2, 1944). The only issue of Na Čužynie (Riga 1920), the organ of Gen. S. Bulakh-Balakhovich and his 'private army', is of interest for the study of this controversial figure who caused the BNR more embarrassment than help. Białoruskie formacje wojskowe 1917-1923 by O. Latyszonek (Białystok 1995) is the first comprehensive study of Belarusian military units. Another recent publication is 'Polskaja polityka na Bielarusi u časie polskabalšavickaj vajny 1919-1920 h.' by F. Kushal in his Sproby stvareńnia bielaruskaha vojska (Minsk 1999).

Very little was written about the BNR by Soviet 13 historians, and almost invariably in a negative manner. The book by Ziuzkoŭ (see above) is a good example. Among more recent publications there are Niepazbiežnaje bankructva by M. Staškievič (Minsk 1974), and also his and I. Kovkel's Pochemu ne sostoialaś BNR? (Minsk 1980), with its English version Why Was the BPR Never Formed? (Minsk 1983). On the other hand there is a great number of works on the establishment of the Belarusian Soviet Republic, practically all suffering from the same defect, namely one-sidedness and the suppression of inconvenient facts. Such are Utvareńnie Bielaruskaj Sacyjalistyčnaj Respubliki (Minsk 1946) and Belorusskii narod v bor'be za sovetskuiu vlast' (Minsk 1963) by N. Kamenskaia; Sozdanie $i$ uprochnenie belorusskoi gosudarstvennosti by S. Margunskii (Minsk 1958); Pobeda sovetskoi vlasti v Belorussii, ed. I. Mints (Minsk 1967). More serious, although still in the same spirit is Rozhdenie Belorusskoi Sovetskoi Respubliki by V. Krutalevich (Minsk 1975). His most recent work, Stanaŭleńnie nacyjanaínaj dziaržaŭnaści (Minsk 1999), written in somewhat different circumstances, contains a wealth of concrete material. Among works by non-Soviet writers one should mention Bol'shevizm na putiakh $k$ ustanovlenii kontrolia nad Belorussiu by $\mathrm{N}$. Nedasek (Munich 1954), and his 'National Self-determination under the Soviets' 
(Belorussian Review, No. 8, Munich 1960), as well as 'The Establishment of the Belorussian SSR' by J. Menski (Ibid., No. 1, 1955).

Belarusian-Polish relations, and in particular the Polish occupation of 1919-20, are dealt with in Adradžeńnie Bielarusi i Polšča by A. Ćvikievič (Berlin 1921); Belorussy i poliaki by K. Jezavitaŭ (Kaunas 1919); Belorusskii vopros k Momentu Versal'skoi Mirnoi Konferentsii by I. Varonka (Kaunas 1919); Polskaja akupacyja Bielarusi by A. Luckievič (Vilna 1920); Uspaminy ab polskaj akupacyi hrodzienščyny by I. Antonaŭ (n.p. 1921), and in the clandestine journal Sialanskaja Dolia (n.p. 1921-22). The Polish position with regard to Belarus is stated in Les Confins Orientaux de la Pologne (Paris 1919), an official publication for the Versailles Conference. Other works include Żywioł polski na ziemiach litewskich by M. Świechowski (Zakopane 1917), Polska a Litwa i Białoruś by J. Sorokowicz (Warsaw 1919; Państwo Polskie a kwestia białoruska by Szczesny Bronowski (Warsaw 1919); Litwa i Białoruś by L. Wasilewski (Warsaw 1925); Sprawa białoruska by S. Elski (Warsaw 1931); Federalizm. Litwa i Białoruś w polityce obozu belwederskiego (XI 1918 - IV 1920) by J. Lewandowski (Warsaw 1962); Polityka Wschodnia Polski wobec ziem Litwy, Białorusi i Ukrainy (1918-1919) by A. Deruga (Warsaw 1969) and others.

The position of Belarusian Catholics and their role in Belarusian national life have been studied by A. Stankievič in his Rodnaja mova ŭ śviatyniach (Vilna 1929) and Bielaruski chrysciański ruch (Vilna 1939). The last two chapters of his Chryscianstva i bielaruski narod (Vilna 1940) are also of considerable interest.

K. Svajak (Fr. K. Stepovič) in his diary Dzieja maioi mysli, serca i voli (Vilna 1932; 2nd ed. London), draws a picture of the difficulties encountered by a young Belarusian Catholic priest in his pastoral work. An interesting work, dealing extensively with this subject is Stosunek Biskupa Jerzego Matulewicza do spraw językowych w diecezji wileńskiej, 1918-1925, by T. Górski (Warsaw 1970). No similar work exists with regard to the Orthodox Church, but some information may be found in the book Belarus by Archbp Afanasi (Buenos Aires 1966; 2nd ed. Minsk 1990). One should also mention the monograph Pakutnik za vieru $i$ baćkaǔščynu by T. Procka (Minsk 1996), about the Orthodox Metropolitan Melchisedek (1876-1931) and his attempts to establish a Belarusian Autocephalous Orthodox Church.

Much useful information can be found in the newspapers of the time, namely Homan (Vilna 1916-18), Bielaruskaje Žyčcio (Vilna 1919), Belarus (Minsk 191920). There are incomplete sets of these publications in the F. Skaryna Library. Starting with 1989 many interesting and valuable articles and hitherto inaccessible materials have appeared in the journals Polymia, Neman and especially Spadčyna, 
all published in Minsk.

The foregoing description does not pretend to be a complete bibliography, but it does show the wealth of material on the struggle of Belarusians for their national identity early in the 20th century, and the proclamation of independence on 25 March 1918. In the years that followed, those who were in power in Belarus did their utmost to make Belarusians forget this event as well as the rest of their history. The consequences of this policy are still felt today.

In 1991, with the collapse of the Soviet Union, Belarus obtained its independence. However, the euphoria created by that event was short-lived. Now Belarus resembles not so much an independent country, but a reservation for aborigines of an almost extinct species known as Homo Sovieticus. It is governed by a regime of doubtful legitimacy and Belarusian only in name. If Belarusians are to have a future as a nation, it is more imperative than ever for them to regain a sense of their history and national dignity. Those are thoughts for the day marking the anniversary of the proclamation of Belarusian independence on 25 March 1918. Incidentally, just like in Soviet times, the official commemoration of this date in present-day 'independent' Belarus is banned. 